\title{
Influence of salinity on COD measurements in coastal water management
}

\section{Zhaoran Li, Yanqing Sheng, Wenjing Shi, Qiyao Sun \& Robert J.G. Mortimer}

To cite this article: Zhaoran Li, Yanqing Sheng, Wenjing Shi, Qiyao Sun \& Robert J.G. Mortimer (2015): Influence of salinity on COD measurements in coastal water management, Desalination and Water Treatment, DOI: 10.1080/19443994.2015.1091996

To link to this article: http://dx.doi.org/10.1080/19443994.2015.1091996

曲 Published online: 21 Sep 2015.

Submit your article to this journal

山 Article views: 19

Q View related articles $₫$

View Crossmark data ¿ 


\title{
Influence of salinity on COD measurements in coastal water management
}

\author{
Zhaoran $\mathrm{Li}^{\mathrm{a}, \mathrm{b}}$, Yanqing Sheng ${ }^{\mathrm{a}, *}$, Wenjing Shi ${ }^{\mathrm{a}}$, Qiyao Sun ${ }^{\mathrm{a}}$, Robert J.G. Mortimer ${ }^{\mathrm{c}}$ \\ ${ }^{a}$ Research Center for Coastal Environment Engineering Technology of Shandong Province, Yantai Institute of Coastal Zone \\ Research, Chinese Academy of Sciences, Yantai 264003, China, Tel. +86 535210 9265; Fax: +86 5352109000 ; \\ emails: zrli@yic.ac.cn (Z. Li),yqsheng@syic.ac.cn (Y. Sheng),wjshi@yic.ac.cn (W. Shi), qiyaosun@163.com (Q.Sun) \\ ${ }^{b}$ College of Research and Environment, University of Chinese Academy of Science, Beijing 100049, China \\ ${ }^{c}$ School of Animal, Rural and Environmental Sciences, Nottingham Trent University, Brackenhurst campus, Southwell, \\ Nottinghamshire NG25 0QF, UK, email: Robert.Mortimer@ntu.ac.uk
}

Received 14 March 2015; Accepted 1 September 2015

\begin{abstract}
Chemical oxygen demand (COD) is an important parameter in water quality assessment. COD values by different determination methods were investigated in coastal rivers. The results show that there is no clear relationship between $\mathrm{COD}_{\mathrm{Cr}}$ and $\mathrm{COD}_{\mathrm{Mn}}$ in coastal areas. $\mathrm{COD}_{\mathrm{Cr}}$ does not reflect the degree of pollution of coastal waters. As salinity increased, $\mathrm{COD}_{\mathrm{Cr}}$ and acidic $\mathrm{COD}_{\mathrm{Mn}}$ increased significantly, but there was little/no change observed for alkaline $\mathrm{COD}_{\mathrm{Mn}}$. Coastal zone water quality standards should be proposed to solve connection problems between marine quality standard and surface water quality standard.
\end{abstract}

Keywords: COD; Salinity; Coastal waters; Water quality standard

\section{Introduction}

Chemical oxygen demand (COD) is one of the most widely used parameters for water quality monitoring and assessment. It provides information about the readily oxidized fraction of the organic load or reduced compounds in waters, indicating the degree of water pollution [1]. COD therefore plays an important role in water pollution control and surface water management [2,3]. According to the species of oxidizing agents, $\mathrm{COD}$ can be divided into $\mathrm{COD}_{\mathrm{Cr}}$ and $\mathrm{COD}_{\mathrm{Mn}}$, depending on whether potassium dichromate $\left(\mathrm{K}_{2} \mathrm{Cr}_{2} \mathrm{O}_{7}\right)$ or potassium permanganate $\left(\mathrm{KMnO}_{4}\right)$ is used as the oxidizing agent in the process of COD analysis [4]. $\mathrm{K}_{2} \mathrm{Cr}_{2} \mathrm{O}_{7}$ has a stronger oxidation capability than $\mathrm{KMnO}_{4}$, and is capable of completely

${ }^{*}$ Corresponding author. oxidizing most organic compounds in water. Generally, $\mathrm{COD}_{\mathrm{Cr}}$ is applied in surface waters (e.g. lakes and rivers) and wastewater, and $\mathrm{COD}_{\mathrm{Mn}}$ is applied in lightly polluted waters, e.g. reservoir, tap water, and seawater. For the determination of COD in coastal waters (river, estuary, and near shore bay), there is no commonly adopted method.

Rapid industrialization, urbanization, and population growth lead to pollution of rivers and estuaries and degradation of ecosystems; therefore, the water quality in the coastal zone is receiving more and more attention [5-7]. COD is the most commonly used indicator to evaluate water quality. However, because $\mathrm{COD}_{\mathrm{Cr}}$ measurement is influenced by high concentrations of chloride or bromine ions $[8,9]$, and $\mathrm{COD}_{\mathrm{Mn}}$ does not reflect the actual degree of pollution, neither method is really applicable to brackish and saline waters. Previous studies on COD have mostly focused 
on how to improve the measurement accuracy e.g. $[1-4,10]$, but relatively few have looked at how to select an appropriate method for a particular salinity [11-13]. In the coastal zone, estuaries vary from brackish to fully saline, and due to the high concentrations of chloride and bromine (which can be oxidized by $\mathrm{K}_{2} \mathrm{Cr}_{2} \mathrm{O}_{7}$ under acid conditions), the $\mathrm{COD}_{\mathrm{Cr}}$ values are elevated. Similarly, heavily polluted river water results in higher $\mathrm{COD}_{\mathrm{Mn}}$ than actual values because of multiple dilutions before analysis. In this study, we applied a systematic testing of both COD methods in three rivers and a reservoir in Yantai (China) in order to determine if there is an optimum approach to measuring COD within the coastal zone, or whether all the existing methods are inappropriate.

\section{Methods and materials}

\subsection{Samples collection and handling}

Water samples were collected from a total of 20 sampling sites in Menlou Reservoir, Jiahe River, Guangdanghe River, and Yuniaohe River in Yantai, China (Fig. 1). All sampling equipment and storage containers were cleaned with distilled water before use. Samples from $\sim 20 \mathrm{~cm}$ below the water surface were taken using 500-mL polypropylene vials. Samples were collected without disturbing the sediment-water interface. The vials were fully filled with water, sealed with gas-tight screw-caps, and immediately kept in an adiabatic box with ice until further analysis. Before analysis, all samples were shaken in a sealed condition.

\subsection{Measurements and methods}

Reagents used were all of analytical grade or above, and deionized water (milli-Q) was used to

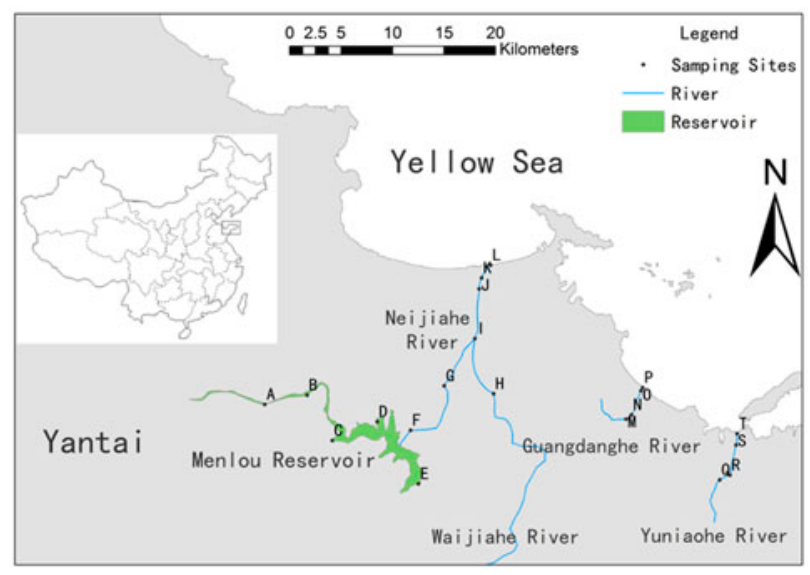

Fig. 1. Schematic graph showing sampling sites. prepare reagent solutions. Concentrations of $\mathrm{COD}_{\mathrm{Cr}}$ and $\mathrm{COD}_{\mathrm{Mn}}$ were measured with the method specified in the standard methods for examination of water and wastewater [APHA, 1998] [14]. Dissolved oxygen (DO), $\mathrm{pH}$, temperature $(T)$, salinity, and oxidation reduction potential (ORP) were measured using a YSI Professional Plus Handheld DO and Temperature System purchased from TechTrend International Limited, USA. The relative standard deviation of the measurements was $<8 \%$ based on triplicate water analyses.

\subsection{Design of modeling test for influence of salinity on COD measurement}

Based on salinity variations in coastal rivers, waters of different salinity were prepared with freshwater (sampled from upstream of the Yuniaohe River) and seawater (offshore area of the Yuniaohe River estuary). Three groups of experiments were set up to determine the different $C O D$ values $\left(\mathrm{COD}_{\mathrm{Cr}}\right.$, acid $\mathrm{COD}_{\mathrm{Mn}}$, and alkaline $\mathrm{COD}_{\mathrm{Mn}}$ ): forty-five $500-\mathrm{ml}$ beakers were divided into three groups of 15 beakers. For each group, different volume ratios of freshwater and seawater were added to these beakers to give a final salinity of 0.5 (100\% freshwater), 1, 2, 3, 4, 5, 6, 7, $8,9,10,12,18,24$, and 31 PSU (100\% seawater), respectively. Then, the different COD were measured to investigate the influence of salinity.

\section{Results and discussion}

\subsection{COD in different coastal rivers and their correlations}

COD values (average of triplicate tests) for different sampling sites in the Guangdanghe River and the Yuniaohe River are presented in Table 1. The concentrations of $\mathrm{COD}_{\mathrm{Cr}}$ were $15-423 \mathrm{mg} \mathrm{L}^{-1}$ in the Guangdanghe River and $31-1,312 \mathrm{mg} \mathrm{L}^{-1}$ in the Yuniahohe River. The concentrations of acidic $\mathrm{COD}_{\mathrm{Mn}}$ and alkaline $\mathrm{COD}_{\mathrm{Mn}}$ were 6-31 and 5-20 $\mathrm{mg} \mathrm{L}^{-1}$ in the Guangdanghe River and 6-24 and 5-25 $\mathrm{mg} \mathrm{L}^{-1}$ in the Yuniaohe River. The highest values of $\mathrm{COD}_{\mathrm{Cr}}$ were recorded in the estuarine sections of both rivers (sites $P$ and T).

The standard electrode potential of $\mathrm{Cl} / \mathrm{Cl}^{-}$ $(1.36 \mathrm{~V})$ and $\mathrm{Br} / \mathrm{Br}^{-}(1.087 \mathrm{~V})$ is much lower than the electrode potential of $\mathrm{Cr}_{2} \mathrm{O}_{7}^{2-} / \mathrm{Cr}^{3+}(1.55 \mathrm{~V})$, so $\mathrm{Cl}^{-}$ and $\mathrm{Br}^{-}$in estuarine water can be oxidized by $\mathrm{K}_{2} \mathrm{Cr}_{2} \mathrm{O}_{7}$ (Eqs. (1) and (2)) during the $\mathrm{COD}_{\mathrm{Cr}}$ analysis process, resulting in elevated measurement values $[8,15]$. Furthermore, the organic matter in all water samples can be oxidized by acidic $\mathrm{K}_{2} \mathrm{Cr}_{2} \mathrm{O}_{7}$ with the help of the silver sulfate catalytic effect (Eq. (3)). In this process, organic matter first oxidizes to organic 

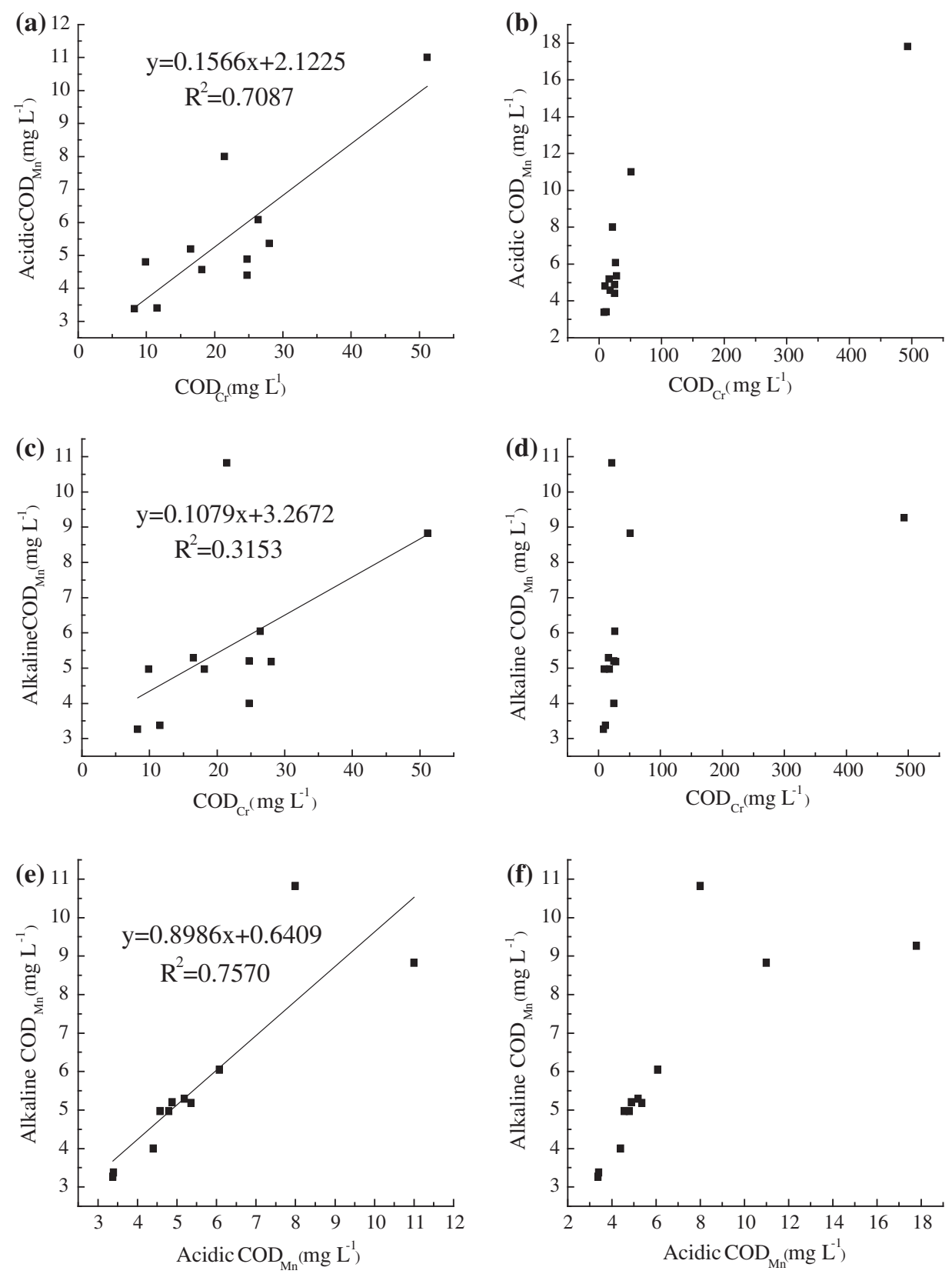

Fig. 2. Relationships among $\mathrm{COD}_{\mathrm{Cr}}$, acidic $\mathrm{COD}_{\mathrm{Mn}}$, and alkaline $\mathrm{COD}_{\mathrm{Mn}}$ in the Jiahe River. (a), (c), and (e) were fitted by data excluding the highly saline point, and (b), (d), and (f) were fitted by the data of all sampling sites.

acid, then reacts with $\mathrm{Ag}^{+}$to form organic acid salts, and then generates carbon dioxide and water. Finally, the organic carbon chains transfer to carbon dioxide and water. Therefore, without the presence of $\mathrm{Ag}^{+}$, organic matter can only be oxidized to organic acid. However, $\mathrm{Cl}^{-}$and $\mathrm{Br}^{-}$in brackish/saline water decrease silver availability by precipitation of solid $\mathrm{AgCl}$ and $\mathrm{AgBr}$. This process restrains the reaction of organic acid into carbon dioxide and water because of $\mathrm{Ag}^{+}$decrease, resulting in a lower $\mathrm{COD}_{\mathrm{Cr}}$ value lower than the actual value. But in comparison, the contribution of the former is larger than that of the latter, so the measurement value is higher than normal. Therefore, $\mathrm{COD}_{\mathrm{Cr}}$ values are not suitable for coastal water quality assessment:

$$
\begin{aligned}
& 6 \mathrm{Cl}^{-}+\mathrm{Cr}_{2} \mathrm{O}_{7}^{2-}+14 \mathrm{H}^{+} \rightarrow 3 \mathrm{Cl}_{2}+2 \mathrm{Cr}^{3+}+7 \mathrm{H}_{2} \mathrm{O} \\
& 6 \mathrm{Br}^{-}+\mathrm{Cr}_{2} \mathrm{O}_{7}^{2-}+14 \mathrm{H}^{+} \rightarrow 3 \mathrm{Br}_{2}+2 \mathrm{Cr}^{3+}+7 \mathrm{H}_{2} \mathrm{O}
\end{aligned}
$$



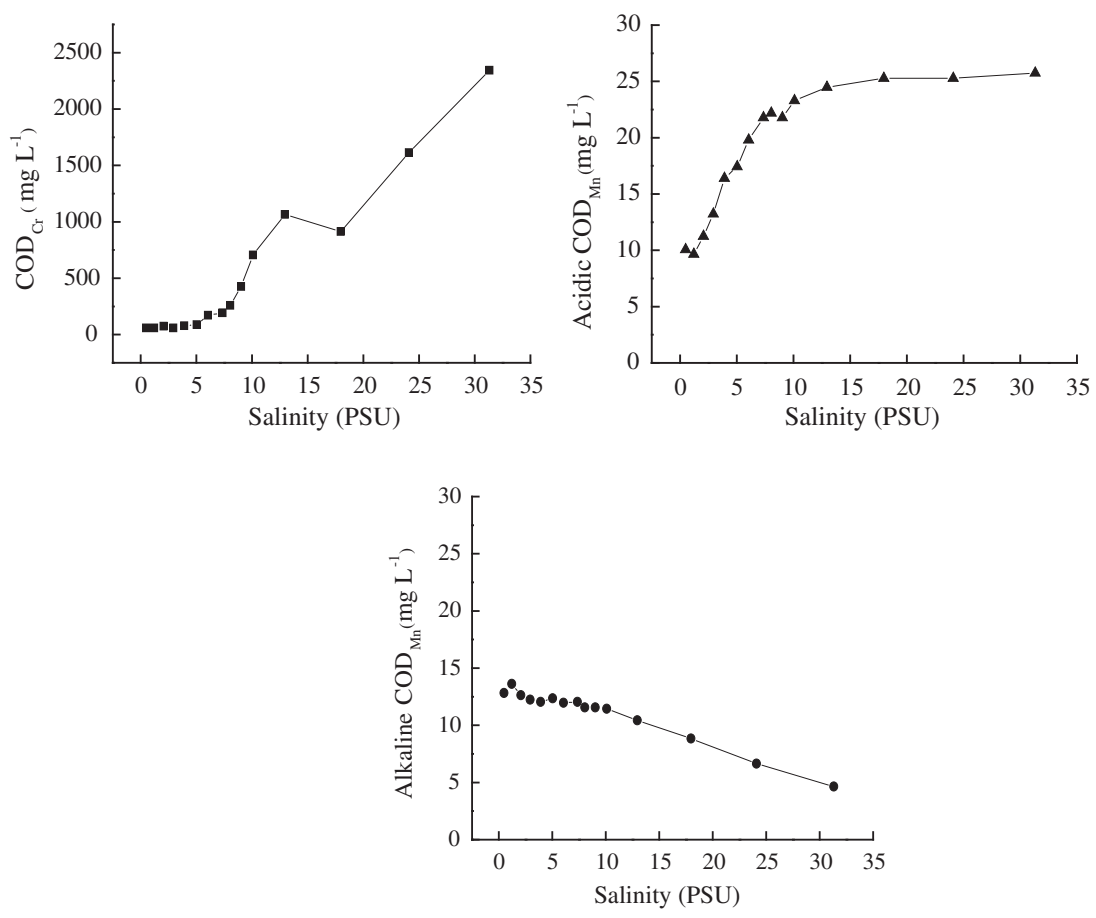

Fig. 3. Influence of salinity on different COD measurements.

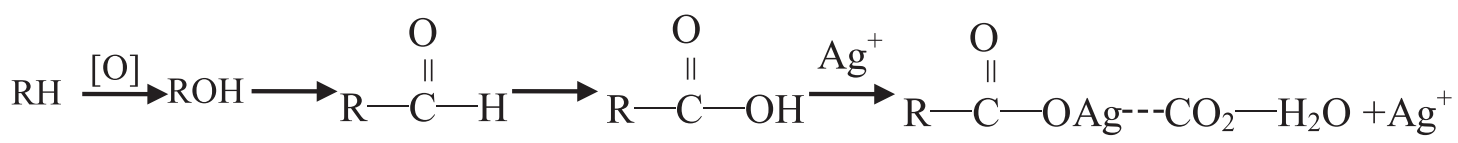

Highest acidic $\mathrm{COD}_{\mathrm{Mn}}$ was measured in the estuarine sites of the Guangdanghe and Yuniaohe rivers. However, alkaline $\mathrm{COD}_{\mathrm{Mn}}$ in these rivers was unstable, and the highest value was not in the estuarine site. This is primarily associated with the unique characteristics of water quality in estuaries and the oxidation strength of oxidants. Under the condition of acidic and alkaline solutions, the standard electrode potential of $\mathrm{MnO}_{4}^{-} / \mathrm{Mn}^{2+}$ is 1.49 and $0.588 \mathrm{~V}$, respectively. So, $\mathrm{Cl}^{-}\left(\mathrm{Cl} / \mathrm{Cl}^{-}, 1.36 \mathrm{~V}\right)$ and $\mathrm{Br}^{-}\left(\mathrm{Br} / \mathrm{Br}^{-}, 1.087 \mathrm{~V}\right)$ in water samples could be oxidized by acidic $\mathrm{KMnO}_{4}$ (Eqs. (4) and (5)) rather than alkaline $\mathrm{K}_{2} \mathrm{Cr}_{2} \mathrm{O}_{7}$ :

$$
\begin{aligned}
& 10 \mathrm{Cl}^{-}+2 \mathrm{MnO}_{4}^{-}+16 \mathrm{H}^{+} \rightarrow 2 \mathrm{Mn}^{2+}+5 \mathrm{Cl}_{2}+8 \mathrm{H}_{2} \mathrm{O} \\
& 10 \mathrm{Br}^{-}+2 \mathrm{MnO}_{4}^{-}+16 \mathrm{H}^{+} \rightarrow 2 \mathrm{Mn}^{2+}+5 \mathrm{Br}_{2}+8 \mathrm{H}_{2} \mathrm{O}
\end{aligned}
$$

For each river, there was a big difference between different COD methods. For example, in the Guangdanghe River, the concentrations of $\mathrm{COD}_{\mathrm{Cr}}$, acidic $\mathrm{COD}_{\mathrm{Mn}}$, and alkaline $\mathrm{COD}_{\mathrm{Mn}}$ were $\sim 430, \sim 32$, and $\sim 20 \mathrm{mg} \mathrm{L}^{-1}$, respectively. This may be related to the oxidation strength of oxidants and the degree of water pollution. $\mathrm{K}_{2} \mathrm{Cr}_{2} \mathrm{O}_{7}$ used in the $\mathrm{COD}_{\mathrm{Cr}}$ analysis is a strong oxidizing agent under acidic conditions (acidity is achieved by the addition of sulfuric acid). It can oxidize almost all organic matter, anions, and oxidizable inorganic materials in waters, including $\mathrm{Cl}^{-}, \mathrm{Br}^{-}$, and $\mathrm{NO}_{2}^{-}$, resulting in high values in different $\mathrm{COD}$ analyses. However, alkaline $\mathrm{KMnO}_{4}$ can merely oxidize some of the organic matter, $\mathrm{NO}_{2}^{-}$and some reductive compounds [16]. Because $\mathrm{Cl}^{-}$and $\mathrm{Br}^{-}$ can be oxidized by acidic $\mathrm{K}_{2} \mathrm{Cr}_{2} \mathrm{O}_{7}$ and acidic $\mathrm{KMnO}_{4}$, the alkaline $\mathrm{KMnO}_{4}$ method was applied in COD measurement in seawater or halogen containing wastewater [13]. 
Table 1

The COD values in the Guangdanghe and Yuniaohe rivers

\begin{tabular}{|c|c|c|c|c|}
\hline & \multirow[b]{2}{*}{ Sampling site } & \multirow[b]{2}{*}{$\mathrm{COD}_{\mathrm{Cr}}\left(\mathrm{mg} \mathrm{L}^{-1}\right)$} & \multicolumn{2}{|c|}{$\mathrm{COD}_{\mathrm{Mn}}\left(\mathrm{mg} \mathrm{L}^{-1}\right)$} \\
\hline & & & Acid method & Alkaline method \\
\hline \multirow[t]{4}{*}{ Guangdanghe river } & $M$ & 15.11 & 5.96 & 5.02 \\
\hline & $N$ & 78.40 & 21.73 & 19.36 \\
\hline & $\mathrm{O}$ & 122.30 & 25.65 & 20.24 \\
\hline & $P$ & 423.36 & 31.53 & 17.44 \\
\hline \multirow[t]{4}{*}{ Yuniaohe river } & $Q$ & 31.36 & 6.24 & 5.33 \\
\hline & $\widetilde{R}$ & 86.24 & 23.84 & 24.56 \\
\hline & $S$ & 47.04 & 7.84 & 5.65 \\
\hline & $T$ & $1,312.42$ & 23.05 & 4.86 \\
\hline
\end{tabular}

In order to investigate the relationship between COD value and salinity, the analysis of waters in the whole watershed of the Jiahe River (from upstream, Menlou reservoir to estuary, Fig. 1) was conducted and the results are listed in Table 2. The concentrations of $\mathrm{COD}_{\mathrm{Cr}}$, acidic $\mathrm{COD}_{\mathrm{Mn}}$, and alkaline $\mathrm{COD}_{\mathrm{Mn}}$ in the Jiahe River were $8-493,3-18$, and $3-11 \mathrm{mg} \mathrm{L}^{-1}$, respectively, with the salinity variation of $0.3-14$ PSU. In the estuary (site $L$ ), the concentrations of $\mathrm{COD}_{\mathrm{Cr}}$ and acidic $\mathrm{COD}_{\mathrm{Mn}}$ reached $\sim 490$ and $\sim 18 \mathrm{mg} \mathrm{L}^{-1}$, respectively, much higher than those in other sites. The value of salinity was 14 PSU at the estuary, which was also much higher than that in other sites of the river. In contrast, $\mathrm{COD}_{\mathrm{Cr}}$ and acid $\mathrm{COD}_{\mathrm{Mn}}$ results were elevated at sites $K$ and $L$ (with high salinity), respectively. These phenomena confirmed the previous hypothesis that COD determination was greatly influenced by salinity except for alkaline $\mathrm{COD}_{\mathrm{Mn}}$.

Generally, $\mathrm{COD}_{\mathrm{Cr}}$ is $2-7$ times higher than $\mathrm{COD}_{\mathrm{Mn}}$ in freshwater, so a rough $\mathrm{COD}_{\mathrm{Mn}}$ value can be obtained through $\mathrm{COD}_{\mathrm{Cr}}$ to assess water quality.
However, in this study, $\mathrm{COD}_{\mathrm{Cr}}$ is orders of magnitude higher than $\mathrm{COD}_{\mathrm{Mn}}$ in the sections with high salinity. Furthermore, there is no obvious correlation between $\mathrm{COD}_{\mathrm{Mn}}$ and salinity in the river-estuary system. Therefore, it is not feasible to get a rough $\mathrm{COD}_{\mathrm{Mn}}$ value from $\mathrm{COD}_{\mathrm{Cr}}$.

Empirically, many engineers use $\mathrm{COD}_{\mathrm{Cr}}$ to estimate a $\mathrm{COD}_{\mathrm{Mn}}$ value in engineering or fieldwork [17,18], but this estimation must rely on stable and simple water chemistry. In this study, the composition of river water was complex (river water plus discharges of wastewater plus tidal mixing with seawater at the seaward end), and there was no obvious positive correlation between $\mathrm{COD}_{\mathrm{Cr}}$ with which to estimate $\mathrm{COD}_{\mathrm{Mn}}$. In order to observe the relationship between $\mathrm{COD}_{\mathrm{Cr}}$, acidic $C O D_{M n}$, and alkaline $C O D_{M n}$ the in Jiahe River, linear fitting of different COD values at each sampling site (Fig. 1) is illustrated in Fig. 2. In this figure, (a), (c), and (e) were fitted by data excluding the highly saline point (sampling point $L$ ), and (b), (d), and (f) were fitted by the data of all sampling sites (point $L$ involved).

Table 2

Parameters in different sampling sites of the Jiahe River valley

\begin{tabular}{|c|c|c|c|c|c|c|c|c|c|}
\hline \multirow[b]{2}{*}{ Site } & \multirow{2}{*}{$\begin{array}{l}\mathrm{DO} \\
\left(\mathrm{mg} \mathrm{L}^{-1}\right)\end{array}$} & \multirow{2}{*}{$\begin{array}{l}\text { Temp. } \\
\left({ }^{\circ} \mathrm{C}\right)\end{array}$} & \multirow{2}{*}{$\begin{array}{l}\text { Cond. } \\
\left(\mathrm{ms} \mathrm{cm}^{-1}\right)\end{array}$} & \multirow{2}{*}{$\begin{array}{l}\text { Sal. } \\
\text { (PSU) }\end{array}$} & \multirow[b]{2}{*}{$\mathrm{pH}$} & \multirow{2}{*}{$\begin{array}{l}\text { ORP } \\
(\mathrm{mV})\end{array}$} & \multirow{2}{*}{$\begin{array}{l}\mathrm{COD}_{\mathrm{Cr}} \\
\left(\mathrm{mg} \mathrm{L}^{-1}\right)\end{array}$} & \multicolumn{2}{|c|}{$\mathrm{COD}_{\mathrm{Mn}}\left(\mathrm{mg} \mathrm{L}^{-1}\right)$} \\
\hline & & & & & & & & Acid & Alkaline \\
\hline$A$ & 7.60 & 26.2 & 0.85 & 0.40 & 8.28 & 265.6 & 24.74 & 4.40 & 4.00 \\
\hline$B$ & 8.69 & 27.3 & 0.87 & 0.41 & 8.57 & 237.1 & 8.25 & 3.38 & 3.26 \\
\hline$C$ & 8.04 & 29.9 & 0.91 & 0.40 & 8.57 & 230.4 & 11.55 & 3.40 & 3.37 \\
\hline$D$ & 8.89 & 30.3 & 0.68 & 0.30 & 9.10 & 305.5 & 28.04 & 5.36 & 5.18 \\
\hline$E$ & 10.77 & 30.8 & 0.62 & 0.26 & 9.34 & 262.8 & 18.15 & 4.57 & 4.97 \\
\hline$F$ & 9.22 & 30.1 & 0.63 & 0.28 & 9.25 & 212.3 & 24.74 & 4.88 & 5.20 \\
\hline$G$ & 9.10 & 28.7 & 0.61 & 0.27 & 9.01 & 254.5 & 9.90 & 4.80 & 4.97 \\
\hline$H$ & 7.87 & 29.6 & 0.73 & 0.33 & 8.82 & 257.2 & 16.50 & 5.19 & 5.29 \\
\hline$I$ & 13.62 & 30.3 & 0.63 & 0.27 & 9.58 & 197.1 & 26.39 & 6.08 & 6.04 \\
\hline$J$ & 14.58 & 29.9 & 0.73 & 0.32 & 9.47 & 179.4 & 21.44 & 8.00 & 10.82 \\
\hline$K$ & 10.44 & 29.7 & 9.11 & 4.61 & 9.02 & 207.6 & 51.14 & 11.00 & 8.82 \\
\hline$L$ & 12.45 & 30.5 & 22.76 & 14.08 & 9.19 & 201.5 & 493.23 & 17.80 & 9.26 \\
\hline
\end{tabular}


A detailed relationship among $\mathrm{COD}_{\mathrm{C}}$, acidic $\mathrm{COD}_{\mathrm{Mn}}$, and alkaline $\mathrm{COD}_{\mathrm{Mn}}$ in the Jiahe River is illustrated in Fig. 2(a)-(f).

From Fig. 2(a), it can be seen that there was a linear correlation between $\mathrm{COD}_{\mathrm{Cr}}$ and acidic $\mathrm{COD}_{\mathrm{Mn}}$ $\left(R^{2} \sim 0.7\right)$, when excluding the highest salinity sample. Although there was a positive correlation between $\mathrm{COD}_{\mathrm{Cr}}$ and acid $\mathrm{COD}_{\mathrm{Mn}}$ in the Jiahe River, no obvious correlation was observed in the Guangdanghe River and the Yuniaohe River (figures not shown). Furthermore, in the Jiahe River, there was nearly no linear relationship (Fig. (c)), $R^{2} \sim 0.3$ between $\mathrm{COD}_{\mathrm{Cr}}$ and alkaline $\mathrm{COD}_{\mathrm{Mn}}$, even with the highest salinity point excluded. Therefore, it is not feasible to get the accurate alkaline $\mathrm{COD}_{\mathrm{Mn}}$ value based on $\mathrm{COD}_{\mathrm{Cr}}$. From Fig. 2(e), the linear relationship $\left(R^{2}\right)$ between acidic $\mathrm{COD}_{\mathrm{Mn}}$ and alkaline $\mathrm{COD}_{\mathrm{Mn}}$ was higher than that between $\mathrm{COD}_{\mathrm{Cr}}$ and alkaline $\mathrm{COD}_{\mathrm{Mn}}\left(R^{2}>0.75\right)$. This was mainly due to the effect of salinity on acidic $\mathrm{COD}_{\mathrm{Mn}}$ being far less than that on $\mathrm{COD}_{\mathrm{Cr}}$ (Fig. (c) and (d)), although the $R^{2}$ value was still decreased after the highly saline point was added (Fig. 2(f)). Overall, when the salinity increased, $\mathrm{COD}_{\mathrm{Cr}}$ and acidic $\mathrm{COD}_{\mathrm{Mn}}$ increased significantly while a little change was observed for alkaline $\mathrm{COD}_{\mathrm{Mn}}$. The coastal zone is a special geographical area, a transition zone from the ocean to the land, with two different unique attributes of sea and land [19]. So, it is unscientific to apply surface water quality standards or sea quality standards separately to assess the coastal water quality. In this study, in the estuaries of three rivers, high $\mathrm{COD}_{\mathrm{Cr}}$ values were found to be mainly due to the high concentration of $\mathrm{Cl}^{-}, \mathrm{Br}^{-}$, and terrigenous contamination. Although the method of alkaline $\mathrm{COD}_{\mathrm{Mn}}$ avoids the influence of tidal seawater, high analytical error occurs during the determination process because of multiple dilutions (heavily polluted water) and complex operation (water bath). Many efforts have been devoted to the development of the photoelectrochemical methods for the determination of COD $[20,21]$. Although these methods could avoid chloride interferences, and without any oxidizing agent addition, there is no unified evaluation criterion on COD in China. Therefore, it is necessary to find a unified method or standard to evaluate water quality in coastal zones.

\subsection{Influence of salinity on COD measurement}

In order to investigate the influence of salinity on COD measurement, the trend of different COD values obtained with salinity is plotted in Fig. 3. There is a linear increase in $\mathrm{COD}_{\mathrm{Cr}}$, up to 5 PSU, but then an exponential increase and more complex trend thereafter. Therefore, 5 PSU can be regarded as the threshold of salinity influence on $\mathrm{COD}_{\mathrm{Cr}}$ measurement.

However, for acid $\mathrm{COD}_{\mathrm{Mn}}$ measurement, there was a rapid linear increase with salinity up to 10 PSU, and then a leveling-off. This phenomenon can be explained because with the salinity increase, the $\mathrm{Cl}^{-}$and $\mathrm{Br}^{-}$in seawater can be oxidized by finite $\mathrm{KMnO}_{4}$. With the volume of seawater increase (along with salinity increase) in model water, finite $\mathrm{KMnO}_{4}$ will be exhausted in the measurement process. So, when salinity exceeds $10 \mathrm{PSU}$, surplus $\mathrm{Cl}^{-}$and $\mathrm{Br}^{-}$are no longer oxidized and the acid $\mathrm{COD}_{\mathrm{Mn}}$ gave similar values (Fig. 3). For alkaline $\mathrm{COD}_{\mathrm{Mn}}$, there is a linear trend here of a gradual decrease in the COD with increased salinity because the pollutants in freshwater were diluted by seawater in model water. Overall, the influence of salinity almost cannot be observed, it is mainly because of weak oxidation capability under alkaline conditions.

\subsection{Application of COD in coastal water quality assessment and management}

Currently, the selection of COD determination method is generally dependent on geographic position in the coastal zone. The $\mathrm{K}_{2} \mathrm{Cr}_{2} \mathrm{O}_{7}$ and acid $\mathrm{KMnO}_{4}$ methods are widely used in river water quality assessment and the alkaline $\mathrm{KMnO}_{4}$ method is used for marine water quality assessment $[22,23]$. In the marine environment, reducible ions in seawater can be oxidized by $\mathrm{K}_{2} \mathrm{Cr}_{2} \mathrm{O}_{7}$ and acid $\mathrm{KMnO}_{4}$ leading to an inaccurate determination result. The content of reductive ions in surface water is generally low $\left(\mathrm{Cl}^{-}<500 \mathrm{mg} \mathrm{L}^{-1}\right)$, while in seawater it is up to $\sim 19,000 \mathrm{mg} \mathrm{L}^{-1}$. Generally, according to the geographical position, intertidal zones in rivers and estuaries are always located inland, but the salinity in these sections may be similar to seawater. Therefore, the $\mathrm{COD}_{\mathrm{Cr}}$ method is unsuitable for such surface water quality assessment. However, for environment management, these sections of the river system often fall under the jurisdiction of the local environmental protection agency, so the method of $\mathrm{COD}_{\mathrm{Cr}}$ will often be blindly applied in water quality management.

In addition to the problem of managing the boundary between inland rivers and the sea itself, there is still no uniform evaluation criterion on COD in China. For example, the environmental quality standard for surface water is divided into five categories, while the marine water quality standard is divided into four grades (Table 3 ), and there are no similar criteria for COD [22,23]. Therefore, if COD was used to assess 
Table 3

Comparison of COD in different water quality standards (unit: $\mathrm{mg} \mathrm{L}^{-1}$ )

\begin{tabular}{|c|c|c|c|}
\hline \multirow[b]{2}{*}{ Level } & \multicolumn{2}{|c|}{ Surface water } & \multirow{2}{*}{$\begin{array}{l}\text { Marine water } \\
\text { Alkaline } \mathrm{COD}_{\mathrm{Mn}}\end{array}$} \\
\hline & $\mathrm{COD}_{\mathrm{Cr}}$ & Acid $\mathrm{COD}_{\mathrm{Mn}}$ & \\
\hline I & $\leq 15$ & $\leq 2$ & $\leq 2$ \\
\hline II & $\leq 15$ & $\leq 4$ & $\leq 3$ \\
\hline III & $\leq 20$ & $\leq 6$ & $\leq 4$ \\
\hline IV & $\leq 30$ & $\leq 10$ & $\leq 5$ \\
\hline $\mathrm{V}$ & $\leq 40$ & $\leq 15$ & - \\
\hline
\end{tabular}

coastal water quality, it is difficult to judge the grade of water quality for coastal waters by this standard. For surface waters, the $\mathrm{K}_{2} \mathrm{Cr}_{2} \mathrm{O}_{7}$ method and the acid $\mathrm{KMnO}_{4}$ method are applied to determine the extent of water pollution, while the $\mathrm{COD}_{\mathrm{Mn}}$ method is used on entering the estuary and off-shore area. Because there are no alkaline $\mathrm{COD}_{\mathrm{Mn}}$ values in the rivers, it is difficult to identify the sources of COD and quantify its influence on coastal water quality.

\section{Conclusions}

$\mathrm{COD}_{\mathrm{Cr}}$ is far higher than $\mathrm{COD}_{\mathrm{Mn}}$ in waters with high salinity within the coastal zone. There is no obvious correlation between $\mathrm{COD}_{\mathrm{Mn}}$ and salinity in the river-estuary-offshore system. It is not feasible to get a rough $\mathrm{COD}_{\mathrm{Mn}}$ value from $\mathrm{COD}_{\mathrm{Cr}}$ measurements, or at least this value does not reflect the real water conditions. The traditional use of geographical location as the dividing line for the method selection of COD measurement is not scientifically rigorous. Instead, a threshold of 5 PSU should be regarded as reference for COD measurement method selection. Although alkaline $\mathrm{COD}_{\mathrm{Mn}}$ for coastal waters presents a steady linear relationship with salinity, it does not reflect real pollution degree because of its weak oxidation capability (most pollutants in surface water cannot be oxidized by $\mathrm{KMnO}_{4}$ under alkaline conditions). Therefore, a special coastal water quality measurement standard should be developed to solve the linking problem of seawater quality standard and surface water quality standard, improving coastal water quality control and management.

\section{Acknowledgments}

This study was supported by the National Natural Science Foundation of China (grant number: 41373100) and Science and Technology Program for Public Wellbeing of Shandong Province (grant number: 2013kjhm060308). Additional support was from Strategic Priority Research Program of the Chinese Academy of Sciences. Sincere gratitude goes to $\mathrm{Dr}$ Jianhui Tang and Dr Guopei Huang of Yantai Institute of Coastal Zone Research, Chinese Academy of Sciences for their assistance in sampling.

\section{References}

[1] C.E. Domini, M. Hidalgo, F. Marken, A. Canals, Comparison of three optimized digestion methods for rapid determination of chemical oxygen demand: Closed microwaves, open microwaves and ultrasound irradiation, Anal. Chim. Acta 561 (2006) 210-217.

[2] A.M.E.V.d. Silva, R.J.N.B.d. Silva M.F.G.F.C. Camões, Optimization of the determination of chemical oxygen demand in wastewaters, Anal. Chim. Acta 699 (2011) 161-169.

[3] H. Yao, B. Wu, H. Qu, Y. Cheng, A high throughput chemiluminescence method for determination of chemical oxygen demand in waters, Anal. Chim. Acta 633 (2009) 76-80.

[4] J. Tian, Y. Hu, J. Zhang, Chemiluminescence detection of permanganate index $\left(\mathrm{COD}_{\mathrm{Mn}}\right)$ by a luminol- $\mathrm{KMnO}_{4}$ based reaction, J. Environ. Sci. 20 (2008) 252-256.

[5] Y. Sheng, Y. Qu, C. Ding, Q. Sun, R.J.G. Mortimer, A combined application of different engineering and biological techniques to remediate a heavily polluted river, Ecol. Eng. 57 (2013) 1-7.

[6] S. Su, D. Li, Q. Zhang, R. Xiao, F. Huang, J. Wu, Temporal trend and source apportionment of water pollution in different functional zones of Qiantang River, China, Water Res. 45 (2011) 1781-1795.

[7] T.P. Ouyang, Z.Y. Zhu, Y.Q. Kuang, Assessing impact of urbanization on river water quality in the pearl river delta economic zone, China, Environ. Monit. Assess. 120 (2006) 313-325.

[8] B. Vaidya, S.W. Watson, S.J. Coldiron, M.D. Porter, Reduction of chloride ion interference in chemical oxygen demand (COD) determinations using bismuthbased adsorbents, Anal. Chim. Acta 357 (1997) 167-175.

[9] S. Belkin, A. Brenner, A. Abeliovich, Effect of inorganic constituents on chemical oxygen demand-I. Bromides are unneutralizable by mercuric sulfate complexation, Water Res. 26 (1992) 1577-1581.

[10] J. Qiu, S. Zhang, H. Zhao, Recent applications of $\mathrm{TiO}_{2}$ nanomaterials in chemical sensing in aqueous media, Sens. Actuators, B: Chem. 160 (2011) 875-890.

[11] F. Raposo, V. Fernández-Cegrí, M.A. De la Rubia, R. Borja, J. Beltrán, C. Cavinato, M. Clinckspoor, G. Demirer, E. Diamadopoulos, J.C. Frigon, J. Koubova, M. Launay, R. Méndez, G. Menin, J. Noguerol, H. Uellehdahl, S. West, Quality improvement in determination of chemical oxygen demand in samples considered difficult to analyze, through participation in proficiency-testing schemes, TrAC, Trends Anal. Chem. 29 (2010) 1082-1091.

[12] A. Drolc, M. Cotman, M. Roš, Uncertainty of chemical oxygen demand determination in wastewater samples, Accredit. Qual. Assur. 8 (2003) 138-145. 
[13] S. Zhang, C. Guo, Research into uncertainty in measurement of seawater chemical oxygen demand by potassium iodide-alkaline potassium permanganate determination method, Mar. Sci. Bull. 9 (2007) 18-24.

[14] APHA, Standard methods for the Examination of Water and Wastewater, twentieth ed., American Public Health Association-American Water Works Association, Baltimore, MD, 1998.

[15] I. Vyrides, D.C. Stuckey, A modified method for the determination of chemical oxygen demand (COD) for samples with high salinity and low organics, Bioresour. Technol. 100 (2009) 979-982.

[16] F.S. Wei, Methods for Monitoring and Analysis of Water and Wastewater, fourth ed., China Environmental Sciences Press, Beijing, China, (China) 2002, pp. 216-219, 223-227.

[17] H.K. Zhou, Relationship between chemical oxygen demand and permanganate index in river water bodies, Environ. Sci. Trends, (China) 2 (2005) 1-2.
[18] X.D. Ju, The relationship between $\mathrm{COD}_{\mathrm{Cr}}$ and $\mathrm{COD}_{\mathrm{Mn}}$ of Yalu River, Mar. Sci. (China) 24 (2000) 7-10.

[19] W.K. Chang, J. Ryu, Y. Yi, W.C. Lee, C.W. Lee, D. Kang, C.H. Lee, S. Hong, J. Nam, J.S. Khim, Improved water quality in response to pollution control measures at Masan Bay, Korea, Mar. Pollut. Bull. 64 (2012) 427-435.

[20] S. Zhang, L. Li, H. Zhao, G. Li, A portable miniature UV-LED-based photoelectrochemical system for determination of chemical oxygen demand in wastewater, Sens. Actuators, B: Chem. 141 (2009) 634-640.

[21] S. Zhang, H. Zhao, A new approach prevailing over chloride interference in the photoelectrochemical determination of chemical oxygen demand, The Analyst 133 (2008) 1684-1691.

[22] SEPA, Environmental quality Standards for Surface Water (GB 3838-2002), China Environmental Sciences Press, (China) 2002.

[23] SEPA, Sea Water Quality Standard (GB 3097-1997), China Environmental Sciences Press, (China) 1997. 